IFN Working Paper No. 923, 2012

Female Representation but Male Rule? Party Competition and the Political Glass Ceiling

\author{
Olle Folke and Johanna Rickne
}




\title{
Female representation but male rule? Party competition and the political glass ceiling*
}

\author{
Olle Folke ${ }^{+}$and Johanna Rickne ${ }^{\psi}$
}

\begin{abstract}
A large literature has studied the context that affects women's numerical representation, but few have moved beyond numbers to study the drivers of a gender gap in political influence among elected politicians. Using panel data for the careers of 35.000 Swedish municipal politicians over six election cycles we first document the said gender gap. Women are substantially less likely to be re-elected for office, which is the most important pre-condition for obtaining influential appointments. Turing to the determinants we find that supply factors, primarily family responsibilities, explain some of this gap. Meanwhile, demand factors such as experience, age, education and income do not. Finding that competition between political parties closes the gap, we argue that a negative bias against women among party selectors thrives in contexts where meritocracy is not enforced. Positive correlations between competition and measures of competence for elected politicians of both genders further support this conclusion.
\end{abstract}

Keywords: Careers in politics, Political competition, Supply of politicians JEL: J45, J16, J21, H0.

\footnotetext{
* We thank Anna Ardin, Pamela Campa, Louise Chappell, Andrew Healy, Lena Hensvik, Jon Fiva, Åsa Ljungvall, Heléne Lundqvist, Per-Anders Edin, Mattias Lundbäck, Astri Muren, Rainbow Murray, Eva Ranelid, Erik Snowberg, and seminar participants at the Public Choice Society Annual Meeting 2012; London School of Economics, VATT, the Annual Conference for Swedish Economists, 2011; RATIO Research Institute, Research Institute for Industrial Economics, The 13th Annual SNEE European Integration Conference, Mölle, Sweden; the Workshop on Electoral Gender Quotas, Washington University, Stockholm School of Economics SITE, Erasmus University, Midwest Political Science Association 2012, and Gothemburg University for helpful comments and suggestions. We also thank Christina Lönnblad for editorial support. Financial support from the Marianne and Marcus Wallenberg Foundation, and the Ragnar Söderberg Foundation, is gratefully acknowledged.

${ }^{+}$Columbia University, SIPA \& Research Institute for Industrial Economics, of2152@ columbia.edu.

${ }^{\psi}$ Research Institute for Industrial Economics \& Uppsala Center for Labor Studies, johanna.rickne@ifn.se.
} 


\section{Introduction}

The under-representation of women in political assemblies is one of the most studied issues in the literature on political selection. This attention has been merited, because having women in political office is important both for the legitimacy of the democratic system (Stevens, 2007) and for policy priorities among elected politicians. ${ }^{1}$

Few studies have moved beyond numbers to analyze the careers of female politicians once they are elected. These careers matter, because elected politicians have vastly different degrees of influence. Chairpersons and party leaders have disproportionate control over the political agenda compared to ordinary representatives of political assemblies (Childs and Krook, 2009; Kittilson, 2010). Descriptive statistics also show that women are under-represented in elevated offices. In 2006 , women constituted $16 \%$ of the world's parliamentarians, $7 \%$ of the ministers, and $3.5 \%$ of the heads of state (Paxton and Hughes, 2007).

We provide the first quantitative study of the determinants of gender differences in one of the key drivers of political influence, namely political career length. Departing from the intuition of the supply and demand model for political recruitment (Norris and Lovenduski, 1995) we test standard explanations of gender differences in representation. We then test whether a negative party bias within party organizations affect women's careers by examining the impact of competition between political parties for women's relative likelihood of being re-elected.

We use panel data for Swedish municipal politicians, a dataset that covers all elected and unelected individuals over six election periods (1991-2010). We combine extensive background data for each of the 150000 politicians in our dataset to meta-variables for changes in competition between political parties over time in each of Sweden's 290 municipalities. The political system in these municipalities mirrors that of the national level in having party-list proportional representation and an indirectly elected executive body composed by the assembly's political majority.

Municipal assemblies are important actors in Sweden's economy: controlling one fifth of Sweden's GDP in public spending, employing one fifth of the country's labor force and levying roughly half of the total tax burden for the average citizen. The composition of these legislative assemblies is thus vital for the Swedish welfare state functions. Municipal politics also constitute the starting point for most political careers. More than three fourths of the current 349 members of the

\footnotetext{
${ }^{1}$ There is evidence that female legislators direct more of their attention to policy areas thought of as "women's issues" (e.g., Welch, 1985; Vega and Firestone, 1995; Norton 1999; Thomas 1991; Swers 2002). The presence of women in legislatures has also been shown to influence the nature of policy outcomes (Besley and Case 2003; Chattopadhyay and Duflo 2004; Clots-Figueras, 2009; Rehavi 2008), and this is the case for Sweden as well (Svaleryd, 2009).
} 
national parliament have previously served in a municipal assembly. Out of the 126 freshmen parliamentarians elected in 2010 , almost half came directly from a municipal assembly. ${ }^{2}$

Our descriptive statistics for the municipal politicians show that many assemblies are close to numerical parity between men and women - reflecting the voluntary, but often strict, gender quotas of the political parties. In more influential positions the gender gap is however wider, reflecting the pyramid shape of most political contexts around the world. After the 2010 election, women constituted $43 \%$ of the municipal assembly members but only $27 \%$ of the chairpersons of the council's board (i.e. the equivalent of the prime minister on the local level).

To study why women fail to advance, we choose the event of re-election as our main outcome variable. This choice is supported by strong positive correlations, for both genders, between the number of re-elections and the likelihood of being appointed to positions that carry more political influence. ${ }^{3}$ On average, each time a politician is re-elected the probability of receiving a chair position in the municipal political system (see section on institutional details for more information) increases by about ten percentage points.

As mentioned above we derive factors expected to affect the nominations of men and women from the supply and demand model for political recruitment (Norris and Lovenduski, 1995). Although it is empirically challenging to measure, and disentangle, the numerous factors that drive supply and demand, we are greatly aided in this effort by our high-quality data. It has the unique feature that we can follow each politician for the full 20-year period, meaning that we can measure critical events that occur both before and after leaving office and which may have differential and gender-related effects on the exit.

Our baseline analysis of the gender difference in re-election shows that the average female politician is $8 \%$ less likely to be re-elected compared to the average male. About half of this disadvantage is explained by our approximations of supply factors: moves, family size and new births, as well as wage increases and job moves on the non-political labor market. When we also add the demand-side controls of education, occupation, age, being foreign-born, the number of previous reelections (i.e. tenure), personal votes ${ }^{4}$ and dummy variables for list rank, the estimated disadvantage of women becomes larger. Hence, women have qualifications that make them more attractive to the parties than their male counterparts, and their weaker career performances exists despite, rather than because of, their formal qualifications.

\footnotetext{
${ }^{2}$ This pattern, which is even more pronounced in earlier periods, is due to the highly localized nomination procedure for parliament where support from party organizations at this level is key

${ }^{3}$ This reflects the importance of seniority for political promotion, as described in detail in the case of the Swedish Parliament by Brothén (2010).

${ }^{4}$ Voters can give one preference vote to a specific politician, but this system has had a limited direct impact on re-election because the few voters that participate mostly vote for high-ranked politicians with "safe seats" on the ballot.
} 
By exploiting differences in political competition across municipalities we test if negative party bias against women can explain their smaller likelihood of re-election. A negative bias could arise if party organizations, the key gatekeepers for political career advancements, make biased evaluations of the qualifications and characteristics of male and female candidates. If women's weaker representation in more influential political positions depends on such a negative bias, we should note more equal career patterns across genders when competition makes biased evaluations more costly, enforcing meritocracy in the promotion process (Becker, 1957).

Following Alesina et al. (1997) Sweden is classified as a two-party system and we measure the main dimension of political competition as the difference in size between the left and the right wing block of political parties. The results show that women's disadvantage occurs primarily in municipalities with weak competition and that increasing competition by one standard deviation cuts their re-election disadvantage in half. This finding is robust to a number of robustness checks and to including municipal fixed effects interacted with the female dummy variable. Changing the level of competition within the same municipality over time improves women's relative re-election rate substantially.

To interpret our findings we take a closer look at a number of possible mechanisms. In line with recent studies linking political competition to the quality of politicians (Besley et al., 2012), our results show that more equally sized political blocks are associated with higher qualifications of those elected. This supports our argument that competition enforces meritocratic nomination processes for influential appointments, thereby counteracting a negative bias against women.

Compared to previous studies linking competition to women's numerical representation (EsteveVolart and Bagues, 2012), our paper adds the insight that competition drives gender equality in political influence by reducing negative party bias against women. This forgoes the prediction that fiercer competition between parties in list PR systems should produce more diverse groups of influential politicians and as a consequence, following the argument of Beaman et al. (2010), higher quality decisions on public spending.

\section{Recruitment and careers of female politicians}

In this section, we depart from the supply-and-demand model for political recruitment to lay the foundation for our study of gender differences in upward career movements. We also review relevant empirical evidence for key aspects of the model and explain our rationale for using political competition as a way of testing the role of negative party bias in women's relative career movements.

The 'supply-and-demand' framework was originally formulated for elections for the British parliament. It has since been used in a multitude of studies of the nomination process for both 
majoritarian and proportional election systems. The model states that the supply of individuals who come forward as aspiring candidates is determined by their access to resources (time and money) and their personal motivation. Which of these aspiring candidates get picked for a position on the ballot is then determined by the party's evaluation. This includes the consideration of their formal merits, as well as the party's perception of how voters will respond to their selection (for example, that 'Voters prefer men').

Supply. It is challenging to distinguishing between supply and demand factors for politicians. Indeed, early studies on supply factors emphasized women's labor force participation and education levels. With the work of Fox and Lawless (2010) on political recruitment, motivational factors took a more central role in the empirical discussion. These authors analyzed panel data on political ambition and recruitment among US citizens in "pipeline professions" (the most common professions for political office holders). Following individuals over time, they found that the lower average level of ambition among women could be fully explained by differences in the recruitment pattern. Women were less likely to be recruited, recruited intensely, or recruited by multiple agents. Of course, Fox and Lawless' work highlights the difficulty in disentangling supply and demand factors. If the lower level of motivation for taking political office among women depends on recruitment practices, "motivation" as a supply factor indeed does not exist independently of party demand.

In the case of Sweden, survey evidence for elected parliamentarians showed no gender-divide in the level of ambition for continued careers (Öhberg, 2011). In the early 2000s, a Swedish survey targeted all politicians who left their elected seats before completing their term in 28 randomly selected municipal assemblies, and returned support for supply explanations for many discontinued careers. The two most common reasons were moving away from the municipality $(21 \%$ of respondents), and changes in the private labor market situation (16\%). Family-related reasons were also mentioned by more than $10 \%$ of the respondents.

Demand. In the theoretical world of supply and demand, political applicants come forward (driven by supply factors), and party organizations then assess their qualifications and decide whether to place them on the ballot. This second part of the process can include both formal and informal judgments of merits. In other words, it can include both a comparison of merits according to some standardized procedure as well as the subjective valuation of these merits mirrored through the eyes of the selector and reflecting also the socioeconomic characteristics of the applicant.

Recent empirical studies have found evidence of negative party bias directed at female politicians. In an empirical study of Spanish senate elections, Esteve-Volart and Bagues (2012) show that Spanish parties strategically allocated women across districts by last name so that the country's quota law was met, but women's last names did not grant them safe seats on the alphabetically ordered lists. In a recent report by the European Commission (2009), lower ballot rankings of women in 
parliamentary elections among EU member states caused the women's average likelihood of election to be only $72 \%$ of the average man's.

One issue that the original supply and demand model, which outlines determinants of who enters politics, does not address is how to think about marginalization once in office. Previous research has shown that women, once elected, are marginalized and excluded from the decision making process. Examples include the exclusion from appointments to high status committees (Heath et al., 2005), from relevant decision making groups such as committees and subcommittees (Hakesworth, 2003) or from the political discussion in those groups (Kathlene, 1994). In the abovementioned survey of reasons for exist among Swedish politician, the third most common reason was a feeling of pointlessness and lack of policy influence. Based on these insights, we argue that marginalization should be considered a demand factor and a channel for negative party bias based on socioeconomic characteristics. In the coming sections, our definition of a negative party bias will hence include not only the formal (and informal) process of nominations for positions on the party ballot, but also bias expressed through the work environment, which also triggers failures of reelection by encouraging exit from the political arena.

Using political competition to test for party bias against women. The prediction that outside competition improves the efficiency of the promotion process in workplaces is a staple good in economics (Becker, 1957). It follows the simple reasoning that selectors may prefer job candidates for socioeconomic characteristics unrelated to their potential job performance, such as gender. When the workplace is facing more outside competition and the pressure for profits increases, recruiters can no longer afford to indulge in their personal preferences, and the social bias in recruitment becomes less pronounced. A simple analogy to the Becker model for the political nomination process requires no more than the non-controversial assumption that voters prefer more competent politicians. In contexts of fiercer competition, adherence to this preference becomes more crucial for an election victory. If women are held back by a lack of qualifications, we should see fewer women in leadership positions where competition makes merit more important for promotion. Conversely, if they are held back by a negative bias among party selectors, competition should make career patterns more equal by enforcing the role of merit in the promotion process.

Several recent papers have shown that competition matters for the socioeconomic characteristics of those elected in a way that supports the positive impact of competition on meritocracy. Nannicini and Galasso (2011) find that central party organizations in Italy chose politicians with higher education and income levels for more closely contested senate races, interpreted by the authors as a more careful application of objective criteria of merit in competitive contexts. Esteve-Volart and Bagues (2012) compare the presence of women in electable position on party lists between Spanish senate races with varying degrees of outcome certainty. They find that uncertain outcomes made it less 
likely that parties nominated women whose last name disqualified them from high-ranked positions on the alphabetically ordered lists. In contested races, the share of female politicians in electable positions grew to match their share on the ballot, interpreted by the authors as evidence of competition counteracting a negative bias.

\section{Institutional Background and Data Description}

\section{Municipal politics and nomination procedures}

Sweden has a proportional election system with semi-open lists at all three levels of government, the national parliament, 20 county assemblies, and 290 municipal assemblies. Municipal assemblies have the right of local self-government which is legally guaranteed by the Swedish Instrument of Government, stipulating that local authorities themselves determine their own affairs under the 1991 Local Government Act 2.1. This includes the power to set local income taxes, which averaged $21.6 \%$ in 2010 . It also includes the main executive responsibility for large areas of social spending, in particular education and elderly care (while health care is managed at the county level), sectors that employ about one fourth of Sweden's total labor force.

Municipalities differ widely in both land area (from 9 to 19,447 square kilometers) and population (from 2,558 to 780,817 inhabitants). Elections are held jointly with the parliament and county levels every fourth year (every third year prior to 1994) and have a participation rate of above $80 \%$. Seats are allocated across parties in proportion to their vote shares in electoral districts with a minimum magnitude of 15 seats.

The legislative chamber of the municipality is called the municipal assembly. It has at least 31 seats and a maximum of 101, with an average of 40. Political power is concentrated to the council board, corresponding to the Government at the national level. Its chairperson is indirectly elected by the governing party or the largest party in the governing coalition, and remaining board seats are distributed amongst all parties to reflect the seat allocation of the full assembly. Specific policy areas are dealt with in subcommittees (the average council has seven of them), to which chairpersons are appointed by the governing majority. The board, assembly and committee chairpersons are the most influential politicians in the local political hierarchy. Usually, only the chair chairperson of the council board is hired full time. Others receive piece rate compensation for meetings and offices, whereof less than $10 \%$ receive more than $40 \%$ of a standard full time salary. A survey carried out in 1991 showed that the average regular council member spent 8.3 hours per week on her duties, while chairpersons spent 17.8 hours.

The party system is highly stable with the seven main political parties represented in nearly all assemblies. Small local parties hold about $4-5 \%$ of the total number of council seats. There is no 
explicit electoral threshold, but an implicit threshold is determined by district magnitude and ranges from about 1.5 to 5 percentage points of the municipal vote.

Party lists are composed in two steps. First, a group of potential candidates is selected either via internal nomination, which is more common in the left-wing parties (Social Democrats and Left Party), or internal primaries in the case of right-wing ones (the Conservative Party, Center Party and the Christian Democrats). Both procedures place substantial authority in the hands of a committee of party selectors. This committee performs several tasks, the first of which is to collect information about aspiring candidates. In the case of the internal nomination procedure, the committee ranks these nominations to a suggested list which is voted on by a member meeting. In the case of the internal primaries, the committee sends the list of nominees to the membership for a vote. This list is often ranked by the committee, or is sent conjoint with party lists from the previous election as "guidance" for the members; actions which qualitative studies have argued introduce an anti-minority bias in the member's voting pattern (Soininen and Etzler, 2006). After the party members' votes are cast, the committee again re-orders the list, although not dramatically.

All main parties have voluntary gender quotas (summarized in Table SI1). Left wing parties have favored stricter quotas with placement mandates, while right wing parties have relied on nonmandatory recommendations for the share of women and emphasized programs of mentorships and training for increasing female leadership. The relevance of these quota policies for our study is further discussed in the sections on descriptive statistics and robustness checks below.

In 1998 Sweden switched from a closed list system to semi-open lists by introducing one voluntary preferential vote per voter. To be elected through the personal vote the politician's personal votes need to number at least 50 and make up at least $5 \%$ of the party's total votes in the district. ${ }^{5}$ In each election, roughly $20 \%$ are elected this way, but of these, more than $95 \%$ already qualified for an assembly seat by their list rank.

\section{Descriptive statistics}

We use data from six waves of municipal elections (1991 to 2010). For each party, we have background information for all candidates on the party lists in each electoral district and from all 290 municipalities. For each list, we know which candidates were elected, their list rank, the number of personal votes they collected and a host of background characteristics. All data are from the official registers of Statistics Sweden, which allows us to follow each individual over the full 1991-2010 period, including years that they are not on a ballot. This sets our dataset apart from other large panels of politicians based on self-reported data from candidates running for office.

\footnotetext{
${ }^{5}$ These rules are constant across parties and municipal assemblies.
} 
In Figure 1 we show the development, over time, of the share of women among the elected politicians and among the first-ranked persons on party ballots (i.e. leader of the party-group). Over our 19 year period, the share of elected women increased from 34.1 to $43 \%$, an increase that was mainly driven by the introduction of a strict gender quota in the largest political party, the Social Democrats, in 1993. The figure also shows the male advantage in holding influential positions. The share of first ranked women increased over the period but did not exceed one third in 2010 . Furthermore, using additional data on the appointments held by each politician in 2006 and 2010, we note that the share of women holding at least one position as chairperson on the municipal council board or in a committee is lower (12.4\%) than that among men (18\%).

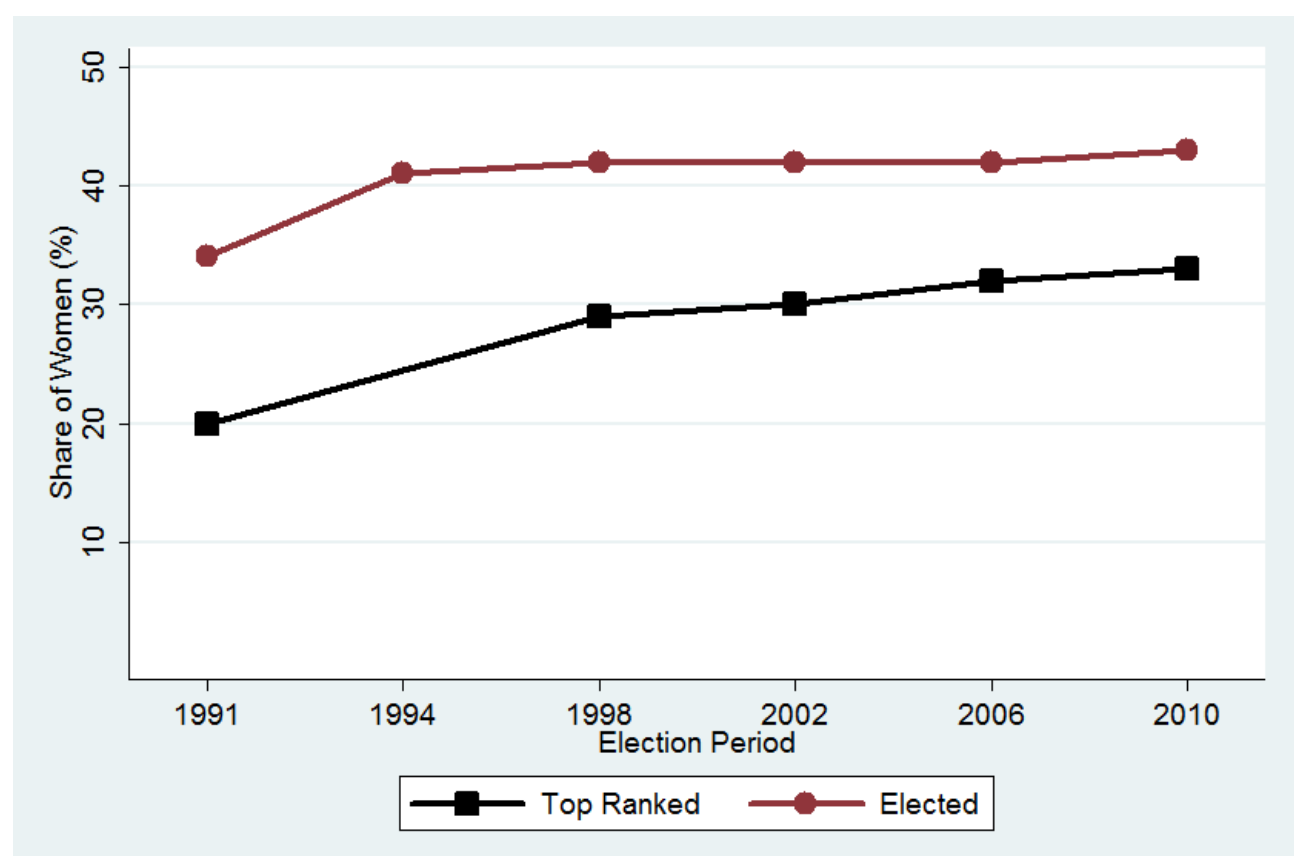

Figure 1. Share of elected women and share of first-ranked women. Information on party group rank is missing for 1994.

Table 1 shows descriptive statistics for elected municipal politicians. Men are, on average, two years older and have higher incomes, while women are more likely to have completed a three-year college degree or above. Women are also more likely to be parents of children aged 0-18. Personal votes are distributed to the advantage of men. It should be noted, however, that this gender difference is to a large extent driven by the higher positions of men on the party ballots, because voters have a tendency to vote for the first name on the list (e.g. Montabes and Ortega, 2002). When we compare the share of personal votes for men and women with the same rank order, the remaining difference across genders is small. T-tests show that all gender differences are statistically significant on the one percent level. 
Table 1. Summary statistics for elected politicians by gender, 1991-2010.

\begin{tabular}{lcccccc}
\hline & Re-elected & Age & Wage & $\begin{array}{c}\text { Higher } \\
\text { education }\end{array}$ & $\begin{array}{c}\text { Parent of } \\
\text { child } \\
\text { of age 0-18 }\end{array}$ & $\begin{array}{c}\text { Share of the } \\
\text { party's total } \\
\text { personal } \\
\text { votes }\end{array}$ \\
\hline All & 55 & 50 & 223.8 & 38 & 36 & 11 \\
Female & 53 & 48 & 201.1 & 42 & 38 & 9 \\
Men & 56 & 51 & 239.4 & 35 & 35 & 12 \\
\hline \hline
\end{tabular}

\section{Political career advancement by gender}

\section{Measuring political influence by the event of re-election}

In this section we empirically motivate our choice of re-election as our main dependent variable. First, we show that re-election to municipal assemblies is key for reaching positions of political influence. Second, we show that women do not benefit from a fast-track to such appointments.

The importance of re-election is closely linked to the important role of the party organization in distributing seats and positions in the list PR system. For individual politicians there is essentially no other route to political influence in local politics, because leadership positions are distributed to those with the highest ranks on the party list and distributed within the parties rather than by popular vote.

Figure 2 shows the correlations between the number of re-elections and the share of male and female politicians that hold two types of leadership positions at the municipal level: 1) a chairpersonship in the municipal council board, the municipal council or a municipal committee, and 2) becoming, or remaining, first-ranked on the party list. For the first outcome we restrict the sample to eligible politicians, those belonging to a party in the governing coalition.

Re-election matters greatly for both genders. The average freshman is about four times less likely to hold a chairpersonship compared to politicians who have served at least four election periods. We can also exclude that women benefit from a fast-track to influence. They are not more likely than men to hold leadership positions for any given number of re-elections. 

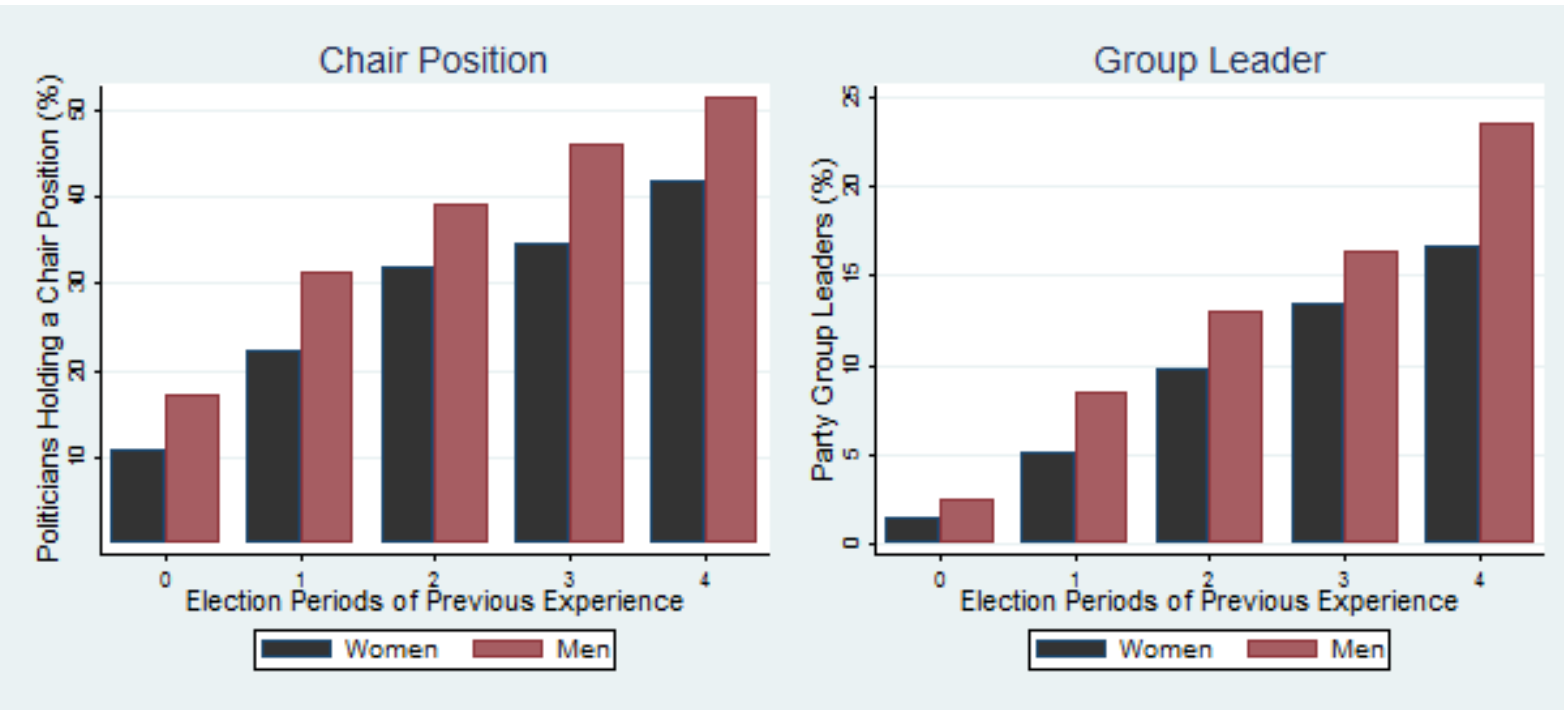

Figure 2. Share of elected men and women with a chair position in the municipal council board, municipal council or committee (left) and first-ranked on a party ballot (right).

In the first part of the Supporting Information Section we provide a regression analysis to corroborate the findings in Figure 2. It shows that the re-election premium noted in the graphical analysis is large, statistically significant, and robust to a large number of control variables. The male advantage is also statistically significant, suggesting that using re-election as a measure of political influence will, if anything, understate women's disadvantage. We also regress election to the national parliament on municipal political experience and draw the corresponding conclusions.

\section{Supply, demand and regression specifications}

To examine if women have a lower probability of being re-elected, we regress the event of reelection in the next election, $Y_{i t+1}$, to either the municipal assembly or the national parliament, ${ }^{6}$ on a host of control variables measured at the time of the current election $t$, according to the specification

$$
Y_{i t+1}=a_{i t}+\beta_{1} w_{i}+\beta_{2} S_{i t}+\beta_{3} D_{i t}+\gamma_{m t p}+\varepsilon_{i t}
$$

\footnotetext{
${ }^{6}$ This is true for about 60 politicians, $0.4 \%$ of the elected, in each election period.
} 
Our main parameter of interest, $\beta_{1}$, is the differential probability of the career advancement for women $\left(w_{i}=1\right)$ relative to men $\left(w_{i}=0\right)$. Our control variables are divided into supply-side controls $\left(S_{i t}\right)$ and demand-side controls $\left(D_{i t}\right)$. Fixed effects are included for the interaction of party $p$, election period $t$ and municipality $m$. Thus, we compare the likelihood of re-election between men and women who are listed on the same party list, and for each given election, removing factors that drive average differences in the likelihood of re-election between parties, municipalities, or election periods. We estimate Equation (1) using OLS instead of a probit for easy interpretation of the coefficients and to avoid biased estimators associated with our numerous fixed effects.

Table 2 shows the results from estimating Equation (1) for seven different specifications where we gradually increase the number of controls. We provide a detailed description of the different set of control variables in the Supporting Information Section, Table SI2. The first specification only includes the female dummy variable to simply capture women's average relative probability of reelection. In specification two, we add controls for the supply of politicians willing to advance. The first pair of controls captures the two most common self-reported reasons for leaving politics: moving to another municipality, or experiencing a change in one's private labor market career. We also control for family responsibilities in two ways: a dummy variable for having a least one child, and a dummy for becoming a parent between elections $t$ and $t+1$. To account for gender differential family responsibilities, we also include an interaction terms between each of these two dummies for family responsibilities and the female dummy. Given that this control captures an explicit gender difference rather than an average supply effect, the point estimate on these interactions are included among the reported estimates in Table 2.

Next, we include the demand-side controls which consist of qualifications that could be evaluated by parties in the recruitment process (cf. Norris and Lovenduski, 1995, p. 107). Due to data availability, we divide these controls into two groups, individual and political. The individual demand controls, which we add in specification three, include the politician's age, education, income, immigration status and vocation. The political demand controls include controls for list rank in the current period, political experience and preferential votes as a share of the party's total votes in the municipality. In very rare cases, the personal vote catapults a politician to an electable seat in $t+1$, which we control for by a dummy variable.

In specifications six and seven, we test two additional ways of controlling for supply-side factors. Specification six excludes all freshmen politicians in election $t$. This addresses the potential concern that weaker motivation among inexperienced politicians, rather than gender, is causing women's weaker career performances.

For completeness, the final specification excludes politicians who do not re-appear on the ballot in election $t+1$. Leaving the list, rather than being moved downward, could be considered a stronger 
indication of a voluntary quit. In reality, however, this measure is highly imperfect. Downward moves are politically and personally sensitive, as they require the acceptance of a lower position in the hierarchy. According to anecdotal evidence, leaving the list altogether is a likely strategy of saving face in that situation and, moreover, negative party bias may also be expressed through marginalization which triggers an exit from the list.

\section{Baseline results}

The results reported in Table 2 can be summarized as follows. Women have a substantially lower probability of re-election, a result that is robust to controlling for the supply of aspiring politicians, as well as for party demand measured by the candidates' formal qualifications and characteristics, including political experience and popularity among voters.

Examining the table column-by-column, the first shows that the average female politician is 3.9 percentage points less likely to be re-elected as compared to the average male. Given that the overall re-election rate is roughly $50 \%$, this translates into an 8 percent lower re-election probability. ${ }^{7}$ Moreover, results apply to each election period, meaning that the gender difference in seniority will be compounded over time.

Adding the supply-side controls (Column 2) shows that these factors play an important role, as the estimated disadvantage is reduced by more than half. In particular, the interaction term between being a parent and being a woman is highly significant and important for the drop in the point estimate on the un-interacted female dummy. This highlights the key role played by family responsibilities for women's weaker career advancements in politics, even in Sweden where childcare is widely available. Here we should however note the difficulty in disentangling supply and demand factors. Changes in family responsibilities can trigger voluntary exits (decreased supply) but also affect the evaluations of individual politicians by the party (decreased demand). Attitudes among party selectors concerning women with children, for example regarding their time available for party work, could also explain the finding.

Introducing the demand-side controls for individual characteristics (specification three) increases the point estimate of women's disadvantage. This means that the average woman possesses characteristics and/or qualifications that make her more attractive to the party as compared to the average man (recall, for example, the descriptive statistics on women's higher educational attainments in Table 1). Women are thus found to have a re-election disadvantage despite their average level of qualifications rather than because of them.

\footnotetext{
${ }^{7}$ Approximately, we can say that the likelihood that a man remains in office is $52 \%$ as compared to $48.1 \%$ for women, a 3.9 percentage point difference. Thus, in percentage terms, men's relative likelihood of re-election is $52 / 48.1 \approx 1.08$, or $8 \%$.
} 
Next, we restrict ourselves to the post 1994 sample, see column 4, and find a larger disadvantage for women. This is driven by gender quota introductions in many parties between 1991 and 1994 (see summary of policies in Table SI1) which improved women election chances in $1994 .{ }^{8}$ When we introduce the controls for political demand-side characteristics in specification 5, the estimate for women's disadvantage shrinks, but remains substantial at 2.9 percentage points. Women's lower level of political experience and smaller receipt of personal votes thus cannot (fully) account for their lower re-election probability. It is perhaps particularly noteworthy that a substantial career disadvantage remains even after taking into account the historical advantage of men by controlling for fixed effects of each position on the party list.

Table 2. OLS estimation results of probability of re-election, 1991-2010.

\begin{tabular}{lccccccc}
\hline & 1 & 2 & 3 & 4 & 5 & 6 & 7 \\
\hline & & & & & & & \\
Woman & & & & & & & \\
& $-3.92^{* * *}$ & $-1.30^{* *}$ & $-2.83^{* * *}$ & $-3.30^{* * *}$ & $-2.93 * * *$ & $-2.04^{*}$ & -0.65 \\
Children * Woman & $(0.46)$ & $(0.58)$ & $(0.64)$ & $(0.80)$ & $(0.78)$ & $(1.07)$ & $(0.75)$ \\
& & $-5.33^{* * *}$ & $-3.38^{* * *}$ & $-3.41^{* *}$ & $-2.84 * *$ & $-3.36^{*}$ & -0.94 \\
New Children * Woman & & $(1.04)$ & $(1.04)$ & $(1.35)$ & $(1.27)$ & $(1.96)$ & $(1.34)$ \\
& & $-4.20^{* *}$ & -0.96 & 1.72 & 0.88 & -2.44 & -1.53 \\
& & $(2.02)$ & $(2.02)$ & $(2.63)$ & $(2.56)$ & $(4.86)$ & $(3.03)$ \\
Observations & & & & & & & \\
\hline Election Sample & 63,484 & 63,484 & 63,428 & 37,552 & 37,267 & 22,208 & 27,207 \\
Supply Controls & $91-2010$ & $91-2010$ & $91-2010$ & $98-2010$ & $98-2010$ & $98-2010$ & $98-2010$ \\
Demand Controls (ind) & & $\mathrm{x}$ & $\mathrm{x}$ & $\mathrm{x}$ & $\mathrm{x}$ & $\mathrm{x}$ & $\mathrm{x}$ \\
Demand Controls (pol) & & & $\mathrm{x}$ & $\mathrm{x}$ & $\mathrm{x}$ & $\mathrm{x}$ & $\mathrm{x}$ \\
Freshmen Omitted & & & & & $\mathrm{x}$ & $\mathrm{x}$ & $\mathrm{x}$ \\
Only on Ballot in t+1 & & & & & & $\mathrm{x}$ & \\
\hline
\end{tabular}

Notes: $* * * \mathrm{p}<0.01, * * \mathrm{p}<0.05, * \mathrm{p}<0.1$. Parenthesis contain robust standard errors. The dependent variable is a dummy for re-election in election $\mathrm{t}+1$. All coefficients are scaled up by 100 to let the point estimates be interpreted as $1.0=1$ percentage point. All specifications include fixed effects for the interaction of year, municipality and party. Definitions of the controls are listed in the Supporting Information.

In specifications six and seven, we restrict the sample with the aim of further controlling for unobserved gender differences in the supply factors of motivation and ambition. When excluding freshmen (Column 6), we see that the disadvantage among incumbent women is smaller than for

\footnotetext{
${ }^{8}$ Instead excluding party-election observations that directly follow a quota adoption gives an even larger estimate of women's disadvantage than removing the two earliest election periods.
} 
newcomers, but that the point estimate remains fairly large. When, instead, excluding politicians who do not re-appear on the ballot in election $t+1$ (Column 7), we find - as expected - that women's lower re-election probability stems from exits from the party list rather than from downward moves.

\section{Robustness for appointments, ideology and election period}

Before moving on, we address some potential robustness concerns. First, we verify that the baseline analysis of women's lower likelihood of re-election indeed reflects a lower degree of access to influential positions. In Table SI4, we repeat the baseline analysis for the outcome of reaching the first-ranked position on a party list. The results strongly support our baseline findings, and also provide some further insights into the size of women's disadvantage in terms of reaching the very top position in the municipal political hierarchy. In relation to the overall average probability of reaching this position, which is $15 \%$, our estimate of a 2 percentage point disadvantage (when including all controls in specification 5) translates into a $13 \%$ smaller likelihood for women compared to men.

Next, we evaluate differences across parties. Among left-wing parties, a stronger ideological emphasis on gender equality could give more parity in career patterns as compared to right-wing parties. In Table SI5, we show the results for the Left block (Pane A), and the Right block (Pane B). The estimates of women's disadvantage are somewhat larger for the right wing block, but the differences are generally not statistically significant.

A third check ensures robustness across election periods (not reported). Women's disadvantage is consistent with the baseline finding for all election periods except the first, 1991 to 1994 . This is, as explained above, due to the introduction of a strict gender quota in the Social Democrats.

Finally, our results are not likely driven by unobserved supply characteristics (motivation and ambition) between male and female politicians. Survey evidence has shown only small gender differences in self-reported motivations for entering municipal politics (Nielsen, 2001) and no differences between the career ambitions among sitting parliamentarians (Öhberg, 2011).

\section{Competition and the political glass ceiling}

Our baseline analysis showed that female politicians are substantially less likely to be re-elected compared to their male counterparts. But despite our numerous control variables, we need further tests to establish the source of this disadvantage. By comparing municipalities with differing degrees of political competition, we can lay the next piece in the puzzle. If women are held back by a lack of qualifications, we should see weaker career performance among women where merit is more important for promotion. Conversely, if they are held back by bias from party selectors, competition should make career patterns more equal by enforcing a meritocratic promotion process (Becker, 1957). 
Measuring competition. This is somewhat in proportional election system complicated since there are more than two parties competing in every given election. In the Swedish setting we can however make use of the fact that politics is centered around two stable left and right wing blocks. ${ }^{9}$ In fact, the strength of the two blocks led to Alesina et al. (1997) classifying Sweden as having a bipartisan political system. This means that the absolute difference in vote shares between these two blocks is an appropriate measure for the main dimension of political competition, which is also the method used in the previous literature (see for example Svaleryd and Vlachos, 2009). ${ }^{10}$ To capture persistence in competition, we use a three-year moving average of the absolute difference in vote shares.

The suitability of our measure can be illustrated in several ways. First, holding a seat majority is relevant for decision making power: in $90 \%$ of the cases when a single party has more than half of the council seats, the chairperson of the council board is a member of that party. Secondly, governing coalitions across the traditional blocks are uncommon, existing in less than one fifth of the cases when one block holds a majority of the seats. Finally, previous research on Swedish municipalities found a causal effect from majority positions of political blocks on political outcomes (Pettersson-Lidbom, 2008).

Because, after all, coalition formation along the right-left divide is not always binding, we construct an alternative competition measure based on the vote share margin of victory for the actual governing coalition. This data is available from the 1994 election onward, so no moving average is used. To allow us to interpret higher values of our two competition measures as more competition, all vote margins are expressed in negative values

Specifications. In Table 3, we report the result from adding an interaction variable between competition and the female dummy to our baseline analysis. Three specifications are used for each competition measure. The first includes the controls for supply and our so-called individual demand variables (Columns 1 and 4). The second adds the political demand controls (Columns 2 and 5), and the third addresses the important concern that municipality characteristics can confound both competition and women's career opportunities. This is motivated by geographical research on Sweden which has argued that women's political representation is highly correlated with regional "cultural" differences (Forsberg, 1997). ${ }^{11}$ Also, descriptive statistics for our sample show that high-competition localities are larger and have citizens with higher levels of both education and income. To capture the gender-related impact of these factors we add municipality fixed effects interacted with the female dummy variable. Reporting the results, we omit the un-interacted female dummy which represents

\footnotetext{
${ }^{9}$ Traditionally, the left-wing block comprises the Social Democrats, the Left Party, and the Green Party, while the right-wing block comprises the Conservative Party, the Center Party, the Liberal Party and the Christian Democrats.

${ }^{10}$ It also means that measuring competition by party concentration is less relevant.

${ }^{11}$ Corresponding to greater "women friendliness" in U.S. Congressional districts that are more urban, ethnically diverse and with higher education levels (Palmer and Simon, 2006).
} 
women's disadvantage in the single reference municipality alone. Since the unit of observation for competition is the municipality we also cluster the standard errors at that level.

Table 3. OLS estimates of competition and probability of re-election, 1991-2010.

\begin{tabular}{lcccccc}
\hline & \multicolumn{3}{c}{ Vote Difference between Blocks } & \multicolumn{4}{c}{ Vote Margin of Governing Coalition } \\
& 1 & 2 & 3 & 4 & 5 & 6 \\
\hline Woman & -1.10 & -1.53 & & $-1.89^{* *}$ & $-1.75^{*}$ & \\
& $(0.90)$ & $(1.07)$ & & $(0.91)$ & $(0.95)$ & \\
Woman * Competition & $9.40^{* * *}$ & $8.14^{*}$ & $24.14^{* *}$ & $27.60^{* * *}$ & $17.58^{* *}$ & $19.97^{*}$ \\
& $(3.60)$ & $(4.23)$ & $(11.84)$ & $(8.02)$ & $(8.44)$ & $(10.27)$ \\
& & & & & & \\
Observations & 63,301 & 37,416 & 63,301 & 42,615 & 30,941 & 42,615 \\
Election Sample & $91-2010$ & $98-2010$ & $91-2010$ & $94-2010$ & $98-2010$ & $94-2010$ \\
\hline Supply Controls & $\mathrm{x}$ & $\mathrm{x}$ & $\mathrm{x}$ & $\mathrm{x}$ & $\mathrm{x}$ & $\mathrm{x}$ \\
Demand Controls (ind) & $\mathrm{x}$ & $\mathrm{x}$ & $\mathrm{x}$ & $\mathrm{x}$ & $\mathrm{x}$ & $\mathrm{x}$ \\
Demand Controls (pol) & & $\mathrm{x}$ & & & $\mathrm{x}$ & \\
Women* Municipality F.E & & & $\mathrm{x}$ & & & $\mathrm{x}$ \\
\hline
\end{tabular}

Notes: $* * * \mathrm{p}<0.01, * * \mathrm{p}<0.05, * \mathrm{p}<0.1$. Parenthesis contain robust standard errors clustered at the municipality level. The dependent variable is a dummy for re-election in election $t+1$. All coefficients are scaled up by 100 to let the point estimates be interpreted as $1.0=1$ percentage point. All specifications include fixed effects for the interaction of year, municipality and party. Definitions control variables are listed in the Supporting Information Section. The vote difference between blocks is defined as the three-year moving average of the absolute vote share difference between the right- and left-wing block. The vote margin of the governing coalition is defined as the difference between the combined vote share of all parties in the governing coalition and $50 \%$ of the vote share. Definitions of the supply and demand controls are listed in the Supporting Information Section.

Results. The main take-away from Table 3 is the positive and statistically significant estimate on the interaction term between political competition and the female dummy. Women's relative likelihood of re-election increases when the two political blocks are of more equal size (Columns 1-3), or when the governing majority has a less dominating hold on power (Columns 4-7). These results are not affected by including municipality fixed effects interacted with the female dummy variable (Columns 3 and 6), allowing us to conclude that they do not stem from un-observed characteristics of the municipality that are constant over time.

The size of the point estimates can be used to quantify the importance of competition as a driver of more equal career patterns. The average difference in vote shares between the right- and left-wing block is 19 percentage points, with a standard deviation of 13 percentage points. A point estimate of 8 , our lower bound, means that increasing competition by one standard deviation raises the relative reelection probability of women by almost 1.5 percentage points, accounting for roughly half of the estimated disadvantage in our most restrictive baseline specification (see Column 5 Table 2). 
Sensitivity checks show that our results are robust to i) excluding the green party from the leftwing block, ii) using vote shares from the national rather than the municipal election, and iii) replacing the moving average of the block difference with the difference after each election. Nor are they driven by stable majorities of one of the blocks; adding an interaction term between the female dummy and the vote share of either block does not affect the results. Moreover, they are robust to replacing the interaction terms between municipal fixed effects and the female dummy with interactions using the municipalities' i) population share with above-high school education, ii) average income level and iii) population (both in linear and log form).

For completeness, we also follow the baseline analysis and omit all freshmen (Table SI6) and those not remaining on party lists in $t+1$ (Table SI7). The results for the first competition measure are robust to omitting the freshmen although statistical significance at the ten percent level is not maintained for the specification with municipality fixed effects interacted with the female dummy. For the second competition measure, the estimates double in size and remain highly significant, indicating that more senior women are the ones whose careers benefit more from political competition. Omitting the politicians that do not remain on the list gives both smaller point estimates and larger standard errors, showing that competition works mainly by men re-appearing on the list more frequently than women.

\section{Mechanisms}

Biased party selectors. Party selectors can play a crucial role in why competition leads to increased gender parity in re-election rates. When motivating our analysis we argued that competition increases their cost for neglecting competent candidates. This would correspond to a more careful screening of politicians of both genders, which we can evaluate by regressing measures of competence of the full municipal assembly on competition. As measures of competence we use education, income (see motivation in Galasso and Nannicini, 2012) and scores from Sweden's military draft exams available for most male politicians (see Besley et al., 2012 for a discussion). The regressions include controls for the average of the dependent variable in question among the municipal population, as well as election year fixed effects.

Results reported in Columns 1-5 of Table 4 indeed show positive relationships between competition and competence, except for the case of the share of women with above high school education. In the case of incomes, the relationship with competition is however equally strong across genders. 
Table 4. Competition and characteristics of municipal assembly members, 1991-2010.

\begin{tabular}{lccccc}
\hline & $\begin{array}{c}1 \\
\text { Education } \\
\text { Women }\end{array}$ & $\begin{array}{c}\text { Education } \\
\text { men }\end{array}$ & $\begin{array}{c}\text { Income } \\
\text { Women }\end{array}$ & $\begin{array}{c}4 \\
\text { Income } \\
\text { Men }\end{array}$ & $\begin{array}{c}\text { Leadership } \\
\text { Score }\end{array}$ \\
\hline \multirow{3}{*}{ Competition } & & & & & \\
& 0.55 & $3.87 * *$ & $49.79 * * *$ & $73.79 * * *$ & $0.81^{* * * *}$ \\
& $(2.13)$ & $(1.86)$ & $(6.83)$ & $(8.57)$ & $(0.17)$ \\
Observations & & & & & \\
\hline
\end{tabular}

Notes: $* * * \mathrm{p}<0.01, * * \mathrm{p}<0.05, * \mathrm{p}<0.1$. Robust standard are reported in parenthesis. The outcome is measured as the average in the municipal council.

The positive correlations with competence suggest that competition pushes selectors to evaluate qualifications more carefully, but it could also impact on the composition of these selectors. As argued by Norris and Lovenduski (1995) the concepts of merit and qualifications are not objective but filtered through ideas about men and women's capacities, which are likely to differ based on who is making the judgment. Studies have showed female selectors to be more appreciative and encouraging toward female candidates (Niven, 1998; 2010) or have more women in their recruitment networks (Sanbonmatsu, 2006). Competition could also foster competent selectors, regardless of gender, who are less threatened by politicians with opposing views (Besley et al., 2012).

Without knowing the precise composition of the selection committee, we follow anecdotal evidence and approximate this group by the three politicians with the highest rank-order on each list. Re-estimating Table 4 for the competence within this smaller group gives positive and statistically significant estimates. Under more competition, the selectors, or at least the party leadership, is more likely to have high incomes, education and leadership scores, and also to be female. However, when we introduce a triple interaction term between the female dummy, the competence of the selectors, and competition, the estimate takes a positive sign but is insignificant. Moreover, the estimate on the woman-competition interaction is not affected. The same result is found for the analogous analysis using the gender composition of the selectors.

Although we cannot provide conclusive evidence, our results provide some interesting suggestive evidence. We show that competition is associated with more meritocratic appointments in general, which could explain why women's relative re-election probabilities improve under these circumstances. However, with the data available to us, we are not able say if this is driven by characteristics of the selectors in places with high competition, or if selectors with a given level of competence make more objective judgments of merit. 
Other possible mechanisms. As shown by Gagliarducci and Paserman (forthcoming), women in political leadership positions achieve greater support for continued careers from female followers within the political body. Moreover, Esteve-Volart and Bagues (2012) connect uncertain races to an increased share of female representatives. In our sample we also see a positive, and significant, estimate when we regress the share of women in parties without strict gender quotas on competition. In these parties, the effect of the number of female followers could indeed contribute to explaining women's greater disadvantage in re-election under weak competition. But because women's disadvantage is also prevalent in parties that have numerical gender parity by force of their quotas, we do not judge this to be the major mechanism in play.

Next, we consider the role of voter preferences. If improved competence of politicians, diversity of politicians, and/or the improved policy making resulting from these sources would not win more votes, competition would not correlate with the politicians' characteristics as shown in Table 4 . Nevertheless, it is reasonable to assume that voter preferences are roughly constant across municipalities, while party selectors' responses to these preferences are the important source of variation for our results. Also, our robustness checks showed that a greater presence of female-friendly voter groups in competitive municipalities (approximated by education and income levels) did not drive our results.

Another potential mechanism is that un-observed levels of ambition of male and female politicians co-vary with competition in a way that explains our results. That increased competition attracts more motivated women is unlikely against the extensive laboratory evidence that women are more risk-averse and reluctant toward participation in competitions (e.g. Gupta et al., 2005; Niederle and Vesterlund, 2007, see also Croson and Gneezy, 2009 for a review). That more ambitious men leave politics when competition is fiercer, giving a downward convergence of their re-election rates to women's level, is also contradicted by the descriptive evidence. The median number of re-election periods for men does not co-vary with our competition measures.

Finally, we note that shifts in political power, which can trigger re-organizations and improved career opportunities, do not have a large explanatory power. Exchanging our competition measure for the share of the governing coalition that is replaced between each pair of elections does not return significant estimates.

\section{Conclusions}

Historically, men held all political positions, but over time previously under-represented socioeconomic groups entered the political arena. The number of women in politics has grown and numerical parity has almost been achieved in some contexts. In this paper we moved beyond numbers 
to assess the gender gap in political influence for those already elected. This is an urgent cause because the influence of elected legislators differs widely, making parity an important pre-condition for equal opportunities to set and pursue policy priorities.

Our case study compared the likelihood for re-election for political office between all male and female Swedish municipal politicians elected during a twenty-year period in 290 municipal assemblies. The results clearly showed that numbers do not automatically bring about influence; female politicians were less likely to be re-elected, in other words to accumulate the political experience and seniority needed for obtaining influential appointments.

When accounting for family structure, changes of residence, and non-political labor market outcomes, women's large re-election disadvantage was cut in half. In particular, being a parent has a differential and large negative impact on women, leading to the (unsurprising) conclusion that gender norms for family related responsibilities should be addressed to improve the democratic representation of women with children. Adding controls for formal qualifications gave a larger estimate for the disadvantage, leading to the conclusion that women faced a disadvantage despite having stronger formal qualifications.

By comparing municipalities in terms of political competition between parties we found that women's disadvantage occurred primarily in contexts characterized by weak competition. This results adds to previous findings that political competition improves political outcomes (Stigler, 1972; Wittman, 1989) the quality of the elected politicians (Besley, et. al., 2012; Nannicini and Galasso, 2011) and the share of elected women (Esteve-Volart and Bagues, 2012) by giving evidence of a strong positive effect of competition on women's relative career performance.

Finding that competition correlated positively with various approximations for competence among the elected (male and female) politicians, we argue competition can trigger equality in reelection rates enforcing meritocracy and stifling a negative bias among party selectors. Although improved access to more influential positions by means of seniority does not automatically grant an equal say in policy decisions (Heath et al., 2005; Gagliarducci and Paserman, forthcoming), reaching them is a necessary pre-condition for eventually bridging the historical gap in policy making power. Based on the fact that elected women have the best opportunities to reach political influence under political competition, we can make the prediction that the impact of female representation on policy should be the largest under political competition.

Making these observations for Sweden - a country that has come far in terms of women's numerical representation - gives an indication of the challenges ahead for other countries. Parity in numerical representation will likely be reached before parity in substantial representation. In this respect, policies aimed at increased gender awareness in parties, such as gender quotas, should not only target women's access to seats, but also their representation on the important seats in terms of agenda setting and policy-making. 


\section{References}

Alesina, Alberto, Roubini, Nouriel, and Cohen, Gerald. (1997). Political Cycles and the Macroeconomy, Cambridge: MIT Press.

Beaman, L., Duflo, E., Pande, R., \& Topalova, P. (2010). Political Reservation and Substantive Representation: Evidence from Indian Village Councils. India Policy Forum, Brookings and NCAER

Becker, Gary S. (1957) The Economics of Discrimination. Chicago: The University of Chicago Press.

Besley, Timothy, Case, Anne (2003). Political Institutions and Policy Choices: Evidence from the United States. Journal of Economic Literature 41(1), 7-73.

Besley, Timothy, Folke, Olle, Persson, Torsten \& Rickne, Johanna (2012). Forced to succeed? Quotas, competition and candidate characteristics. Manuscript in preparation

Chattopadhyay, Raghabendra, Duflo, Esther (2004) Women as policy makers: Evidence from a randomized policy experiment in India. Econometrica 72(5), 1409-1443.

Childs, Sarah and Krook, Lena Mona (2009) Analysing women's substantive representation: From critical mass to critical actors. Governments and Opposition 44(2), 125-145.

Clots-Figueras, Irma (2011) Are female leaders good for education? Evidence from India, American Economic Journal Applied Economics, forthcoming.

Croson, Rachel, Gneezy, Uri (2009) Gender differences in preferences. Journal of Economic Literature 47(2), 448-474.

Esteve-Volart, Berta and Manuel, Bagues (2012) Are women pawns in the political game? Evidence from elections to the Spanish senate. Journal of Public Economics 96(3-4), 387-399.

European Commission (2009) Women in parliament - Time for action. Luxembourg: Office for Official Publications of the European Communities.

Fox, Richard L and Lawless, Jennifer L. (2010) It Still Takes A Candidate: Why Women Don't Run for Office. New York: Cambridge University Press.

Forsberg, Gunnel (1997) Rulltrappregioner och social infrastruktur (escalator regions and social infrastructure), i Sunding Elisabeth, Om makt och kön (Power and gender), SOU 1997:83, Stockholm: Fritzes.

Freidenvall, Lenita, Dahlerup, Drude, Skeije, Hege (2006) The Nordic countries: An incremental model, in Dahlerup, Drude (Ed.) Women, quotas and politics. Oxon and New York: Routledge.

Galasso, Vincenzo and Nannicini, Tommaso (2011) Competing on good politicians. American Political Science Review, 105, 79-99.

Gagliarducci, Stefano, Paserman, Daniele, M. (forthcoming) Gender interactions within hierarchies: Evidence from the political arena, Review of Economic Studies.

Gupta, Datta, Poulsen, Anders, N. Villeval, Marie, C. (2005) Male and Female Competitive BehaviorExperimental Evidence, IZA Discussion Paper No. 1833 
Heath, Michelle, Schwindt-Bayer, Leslie, Taylor-Robinson, Michelle (2005) Women on the Sidelines: Women's Representation on Committees in Latin American Legislatures. American Journal of Political Science 49(2), 420-436.

Hakesworth, Mary (2003) Congressional enactments of race-gender: Toward a theory of racegendered institutions. American Political Science Review 97(4), 529-549.

Kathlene, Lyn (1994) Power and Influence in State Legislative Policymaking: The Interaction of Gender and Position in Committee Hearing Debates. American Political Science Review 88(3), 560-576.

Kittilson, Miki Caul (2010) Women, parties and platforms in postindustrial democracies. Party Politics 17(1), 66-92.

Krook, Mona, L., Lovenduski, Joni, Squires, Judith (2006) Western Europe, North America, Australia and New Zealand, in Dahlerup, Drude (Ed.) Women, quotas and politics. Oxon and New York: Routledge.

Montabes Pereira, J., Ortega, Carmen, V. (2002) Position Effects and Party Nomination Strategies under the Limited Vote: The 2000 Spanish Senate Election, Representation 38(4), 304-16.

Niederle, Muriel, Vesterlund, Lise (2007) Do women shy away from competition? Do men compete too much?. Quarterly Journal of Economics 122(3), 1067-1101. .

Nielsen, Peder (2001) På och av - om uppdragsvillighet, rekrytering och avhopp i den kommunala demokratin (On and off - motivation for public office, recruitment and quits in the municipal democracy). in Att vara med på riktigt. Bilagor till betänkande av Kommundemokratikommittén. Bilaga till SOU 2001:48.

Niven, David (1998) The Missing Majority: The Recruitment of Women as State Legislative Candidates. Westport, CT: Praeger.

Niven, David (2010) Party Elites and Women Candidates: The Shape of Bias, in Women, gender and politics: A reader. Krook, Mona, L. (Ed), Oxford: Oxford University Press.

Norris, Pippa and Lovenduski, Joni (1995) Political Recruitment: Gender, Race and Class in the British Parliament. Cambridge University Press: Cambridge

Paxton, Pamela Marie and Hughes, Melanie M. (2007) Women, Politics, and Power: A Global Perspective. Pine Forge Press, Los Angeles.

Palmer, Barbara and Dennis Simon (2006) Breaking the Political Glass Ceiling: Women and Congressional Elections. New York: Routledge.

Pettersson-Lidbom, Per (2008) Do parties matter for economic outcomes? A regression-discontinuity approach. Journal of the European Economic Association 6(5), 1037-1056.

Rehavi, Marit M. (2008) Sex and politics: Do female legislators affect state spending?. Mimeo, Berkeley.

Sanbonmatsu, Kira (2006) Where Women Run: Gender and Party in the American States. Ann Arbor: University of Michigan.

Soininen, Maritta, Etzler, Nils (2006) Partierna nominerar: Exkluderingens mekanismer - etnicitet och representation (Political parties nominate: Mechanisms of exlution - ethnicity and representation. SOU 2006:53.

Stevens, Anne (2007). Women Power and Politics. Palgrave Macmillan, London.

Stigler, George. J. (1972). Economic Competition and Political Competition. Public Choice 13: 91106. 
Svaleryd, Helena (2009) Women's representation and public spending. European Journal of Political Economy 25(2), 186-198.

Svaleryd, Helena and Vlachos, Jonas (2009) Political rents in a non-corrupt democracy. Journal of Public Economics 93(3-4), 355-372.

Swers, Michele, L. (2002) The difference women make: the policy impact of women in congress. University of Chicago Press: Chicago.

Vega, Arturo, Firestone, Juanita M. (1995) The effects of gender on congressional behavior and the substantive representation of women. Legislative Studies Quarterly 20(2), 213-222.

Welch, Susan (1985) Are women more liberal than men in the U.S. Congress?. Legislative Studies Quarterly 10, 125-134.

Wittman, Donald., 1989. Why Democracies Produce Efficient Results. Journal of Political Economy97(6), 1395-1424.

Öhberg, Patrik (2011) Politiker med karriärambitioner - en omöjlig självklarhet (politicians with career ambitions - a contradiction) Ph.D. Thesis, University of Gothemburg, Department of Political Science.

\section{Supporting Information}

Table SI1 Gender quota characteristics and implementation years in Swedish political parties.

\begin{tabular}{|c|c|c|c|}
\hline Party & Year & $\begin{array}{l}\text { Mandatory quotas and } \\
\text { placement mandates } \\
\text { (hard quotas) }\end{array}$ & $\begin{array}{l}\text { Targets and recommendations } \\
\text { (soft quotas) }\end{array}$ \\
\hline \multirow[t]{3}{*}{ Left party } & 1987 & $\begin{array}{l}\text { Share of women at least equal } \\
\text { to the female share of the } \\
\text { constituency }\end{array}$ & \\
\hline & 1993 & Minimum $40 \%$ of either sex & \\
\hline & 1997 & Minimum $50 \%$ female & \\
\hline \multirow[t]{3}{*}{ Social democrats } & 1987 & & $\begin{array}{l}\text { Minimum representation of } 40 \% \\
\text { women at all party levels }\end{array}$ \\
\hline & 1990 & & Equal representation of the sexes \\
\hline & 1993 & $\begin{array}{l}50 \%, \text { plus mandatory } \\
\text { alternation of male and } \\
\text { female names }\end{array}$ & \\
\hline \multirow[t]{2}{*}{ Green party } & 1987 & $40 \%$ & \\
\hline & 1997 & $50 \%$, plus minus one person & \\
\hline \multirow[t]{2}{*}{ Liberal party } & 1974 & & $40 \%$ \\
\hline & 1984 & & $\begin{array}{l}50 \% \text {, plus mandatory alternation } \\
\text { of male and female names }\end{array}$ \\
\hline Christian democrats & 1987 & & Minimum $40 \%$ of either sex \\
\hline Center party & 1996 & & Equal representation of the sexes \\
\hline Conservative party & 1993 & & Equal representation of the sexes \\
\hline
\end{tabular}

Source: Authors' own classification based on Krook et al. (2006) and Freidenvall et al. (2006). 
Table SI2 Variable definitions

Supply factors

Family responsibilities

Labor market changes

Moving
Dummy variable for having at least one child with between 0 and 18 years of age

Dummy variable for getting at least one more child between $t$ and $t+1$

Dummy variable for increasing one's real income by more than 25 percentage points between $t$ and $t+1$

Dummy variable for changing one's sector of employment between $t$ and $t+1$

\section{Individual demand factors}

Age

Education

Income

Immigrant

Vocation
Dummy variable for changing residence to another municipality between $t$ and $t+1$
Categorical dummy variables for the age groups of 18-29, 30-49, 50-60, 61-64, and 65 or above.

Categorical dummy variables for seven levels of education, ranging from having less than nine years of schooling to having a doctorate degree

Log of real wage

Dummy variable for being foreign-born

Categorical dummy variables for ten employment sectors

\section{Political demand factors}

Previous experience

Current position/ranking
Categorical dummy variables for the number of previous periods served on the municipal council. Since this variable data is censored in 1991, we include a separate set of dummies for each election period. 
within the party group

Personal Votes effect of ranking on the probability of re-election could be dependent on the size of the party group, we interact these fixed effects with four categorical dummy variables for the size of the party group.

Personal votes received by each politician as a share of the party's total number of personal votes

Dummy variable for passing the election threshold for the personal vote

Dummy variable for election by personal vote from a position on the ballot that would not otherwise have qualified the politician for a seat

\section{Seniority and appointments}

This section contains a formal analysis the relationship between re-election and political power. We regress three measures of political career advancement on the number of times a politician has been re-elected for the municipal assembly and report the results in Table SI3. Odd numbered columns include only dummy variables for having served at least one, at least two and at least three terms. Even numbered columns also include interaction terms between these dummies and the dummy for being a woman, with the aim of evaluating whether women benefit from a fast track to influence. All estimations include both supply and demand control variables from our baseline regression.

The first two outcome variables in Table SI3 are the same as for the graphical analysis in Section 3.2, namely holding a chairpersonship (Columns 1 and 2) and becoming or remaining firstranked on the party list (Columns 3 and 4). The third outcome variable (Columns 5 and 6) captures election for the parliament in the next election period.

The results speak strongly in favor of our choice of municipal assembly re-election as a major driver of political influence, both at the municipal and national level. The estimates on the number of terms served in the municipal assembly are positive, highly significant, and increasing in size with the number of terms. Compared to the estimates for the municipal appointments, the ones for parliamentary seats are smaller, a result that is likely to stem from two sources. First, in each election period only about 130 out of 13000 municipal politicians are elected to parliament in the next election 
period. Moreover, municipal politics are not always an inferior career option, in particular when comparing influential municipal appointments in large municipalities to freshman status in the national assembly. This is likely why the probability of advancing to the national assembly does not increase when one moves from two to three periods of previous political experience. ${ }^{12}$

Table SI3. OLS estimates of correlations between the number of re-elections to the municipal assembly and a dichotomous measure of holding an influential position in municipal or national politics

\begin{tabular}{|c|c|c|c|c|c|c|}
\hline & \multicolumn{2}{|c|}{$\begin{array}{c}\text { Municipal Chairperson of } \\
\text { Board or Committee }\end{array}$} & \multicolumn{2}{|c|}{$\begin{array}{l}\text { First-Ranked on } \\
\text { Municipal ballot }\end{array}$} & \multicolumn{2}{|c|}{$\begin{array}{l}\text { Elected for } \\
\text { Parliament }\end{array}$} \\
\hline & 1 & 2 & 3 & 4 & 5 & 6 \\
\hline 1 Period & $\begin{array}{c}8.92 * * * \\
(0.98)\end{array}$ & $\begin{array}{c}9.51^{* * * *} \\
(1.38)\end{array}$ & $\begin{array}{c}4.03^{* * *} \\
(0.35)\end{array}$ & $\begin{array}{l}4.76^{* * *} \\
(0.52)\end{array}$ & $\begin{array}{l}0.25^{* *} \\
(0.11)\end{array}$ & $\begin{array}{c}0.09 \\
(0.14)\end{array}$ \\
\hline 1 Period $*$ Woman & & $\begin{array}{l}-1.26 \\
(1.89)\end{array}$ & & $\begin{array}{c}-1.62 * * \\
(0.69)\end{array}$ & & $\begin{array}{c}0.34 \\
(0.23)\end{array}$ \\
\hline 2 Periods & $\begin{array}{c}15.34 * * * \\
(1.21)\end{array}$ & $\begin{array}{c}15.17 * * * \\
(1.63)\end{array}$ & $\begin{array}{c}7.73 * * * \\
(0.50)\end{array}$ & $\begin{array}{c}8.75 * * * \\
(0.70)\end{array}$ & $\begin{array}{c}0.54 * * * \\
(0.16)\end{array}$ & $\begin{array}{c}0.28 \\
(0.18)\end{array}$ \\
\hline 2 Periods $*$ Woman & & $\begin{array}{c}0.56 \\
(2.32)\end{array}$ & & $\begin{array}{c}-2.23 * * \\
(0.97)\end{array}$ & & $\begin{array}{l}0.58 * \\
(0.31)\end{array}$ \\
\hline 3 Periods & $\begin{array}{c}22.90 * * * \\
(1.12)\end{array}$ & $\begin{array}{c}24.26 * * * \\
(1.44)\end{array}$ & $\begin{array}{c}15.63 * * * \\
(0.50)\end{array}$ & $\begin{array}{c}17.30 * * * \\
(0.64)\end{array}$ & $\begin{array}{c}0.51 * * * \\
(0.13)\end{array}$ & $\begin{array}{c}0.40^{* * * *} \\
(0.15)\end{array}$ \\
\hline 3 Periods * Woman & & $\begin{array}{l}-3.29 * \\
(1.97)\end{array}$ & & $\begin{array}{c}-4.55^{* * *} \\
(0.93)\end{array}$ & & $\begin{array}{c}0.26 \\
(0.25)\end{array}$ \\
\hline Woman & & $-7.38 * * *$ & & $-2.17 * * *$ & & -0.18 \\
\hline
\end{tabular}

${ }^{12}$ According to anecdotal evidence from the authors' own interviews with party organizers, nominations to the national assembly are also sometimes used to free municipal elites from candidates with diverging opinions. 


\begin{tabular}{lcccccc} 
Observations & 12,717 & 12,717 & 29,177 & 29,177 & 24,582 & 24,582 \\
\hline Election Sample & $2006-10$ & $2006-10$ & $2002-10$ & $2002-10$ & $2002-06$ & $2002-06$
\end{tabular}

Notes: $* * * \mathrm{p}<0.01, * * \mathrm{p}<0.05, * \mathrm{p}<0.1$. The sample is censored at 2002 to allow meaningful comparisons of the number of re-elections. Robust standard errors clustered at the municipality level are reported in parenthesis. The dependent variable is a dummy for holding the position listed in the top row in election $t+1$. All coefficients are scaled up by 100 to let the point estimates be interpreted as $1.0=1$ percentage point. All specifications include fixed effects for the interaction of year, municipality and party as well as control variables for: having at least one child; moving to another municipality in $t+1$; log of market wage; dummies for four age categories, seven categories of educational attainment, ten categories for vocation; being born in a foreign country. For Columns 1 and 2 we use only party groups that form part of the governing majority in the municipality. For Columns 3 and 4 we exclude party groups with five or fewer elected politicians.

Using gender differences in re-election rates to approximate career advancements is only appropriate to the extent that women and men are given equal career pay-offs from being re-elected. If women benefit from fast tracks to appointments, our analysis risks to exaggerate the career disadvantage resulting from a lower rate of re-election. An examination of the estimated interaction effect between re-election and gender however shows that being a woman is not associated with greater career pay-offs to political experience. The exception is the coefficient on being promoted to a seat in the national parliament after having served at least two terms in the municipal assembly. Because of the small share of politicians make this particular career move each term, we are not concerned about the general gender neutrality (or at least not pro-women-bias) of our dependent variable.

\section{Robustness checks}

Table SI4. OLS estimation results for the probability of reaching the top ranked position on a party list, 1991-2010.

\begin{tabular}{|c|c|c|c|c|c|c|c|}
\hline & 1 & 2 & 3 & 4 & 5 & 6 & 7 \\
\hline Woman & $\begin{array}{c}-4.43 * * * \\
(0.32)\end{array}$ & $\begin{array}{c}-3.60 * * * \\
(0.39)\end{array}$ & $\begin{array}{c}-4.10 * * * \\
(0.41)\end{array}$ & $\begin{array}{c}-4.23 * * * \\
(0.57)\end{array}$ & $\begin{array}{c}-1.73 * * * \\
(0.44)\end{array}$ & $\begin{array}{c}-1.45 * * \\
(0.59)\end{array}$ & $\begin{array}{c}-1.81 * * * \\
(0.57)\end{array}$ \\
\hline Children $*$ Woman & & $\begin{array}{c}-2.00 * * * \\
(0.72)\end{array}$ & $\begin{array}{c}-1.26 * \\
(0.71)\end{array}$ & $\begin{array}{l}-1.29 \\
(0.98)\end{array}$ & $\begin{array}{l}-0.35 \\
(0.76)\end{array}$ & $\begin{array}{l}-0.50 \\
(1.22)\end{array}$ & $\begin{array}{c}0.05 \\
(0.94)\end{array}$ \\
\hline New Children * Woman & & $\begin{array}{l}-0.87 \\
(1.33)\end{array}$ & $\begin{array}{c}0.72 \\
(1.33)\end{array}$ & $\begin{array}{c}1.76 \\
(1.70)\end{array}$ & $\begin{array}{l}-0.99 \\
(1.49)\end{array}$ & $\begin{array}{l}-2.37 \\
(2.99)\end{array}$ & $\begin{array}{l}-3.70 * \\
(2.06)\end{array}$ \\
\hline Observations & 63,485 & 63,485 & 63,429 & 37,553 & 37,268 & 22,209 & 27,209 \\
\hline
\end{tabular}




\begin{tabular}{|c|c|c|c|c|c|c|c|}
\hline Election Sample & $91-2010$ & $91-2010$ & $91-2010$ & $98-2010$ & $98-2010$ & $98-2010$ & $98-2010$ \\
\hline Supply Controls & & $\mathrm{x}$ & $\mathrm{x}$ & $\mathrm{x}$ & $\mathrm{x}$ & $\mathrm{x}$ & $\mathrm{x}$ \\
\hline Demand Controls (ind) & & & $\mathrm{x}$ & $\mathrm{x}$ & $\mathrm{x}$ & $\mathrm{x}$ & $\mathrm{x}$ \\
\hline Demand Controls (pol) & & & & & $\mathrm{x}$ & $\mathrm{x}$ & $\mathrm{x}$ \\
\hline Freshmen Omitted & & & & & & $\mathrm{x}$ & \\
\hline Only on Ballot in $t+1$ & & & & & & & $\mathrm{x}$ \\
\hline
\end{tabular}

Notes: $* * * \mathrm{p}<0.01, * * \mathrm{p}<0.05, * \mathrm{p}<0.1$. Robust standard errors clustered at the municipality level are reported in parenthesis. The dependent variable is a dummy for attaining or maintaining the first rank on the party list in election $t+1$. All coefficients are scaled up by 100 to let the point estimates be interpreted as $1.0=1$ percentage point. All specifications include fixed effects for the interaction of year, municipality and party. For definitions of the supply and demand controls, see Table SI2.

Table SI5. OLS estimation results of probability of re-election, 1991-2010, by ideological block.

\begin{tabular}{lccccccc}
\hline & 1 & 2 & 3 & 4 & 5 & 6 & 7 \\
\hline A. LEFT BLOCK & & & & & & & \\
Woman & $-3.44 * * *$ & -0.60 & $-1.68^{* *}$ & $-1.67 *$ & $-1.86^{*}$ & -0.99 & 0.50 \\
& $(0.54)$ & $(0.71)$ & $(0.76)$ & $(1.01)$ & $(1.05)$ & $(1.38)$ & $(0.96)$ \\
Children * Woman & & $-5.50^{* * *}$ & $-3.72^{* * *}$ & $-3.99^{* *}$ & $-3.69^{* *}$ & $-4.85^{*}$ & -1.49 \\
& & $(1.80)$ & $(1.83)$ & $(2.25)$ & $(2.18)$ & $(3.86)$ & $(2.53)$ \\
New Children * Woman & & $-4.72^{*}$ & -1.47 & 2.70 & 1.51 & -3.31 & 0.17 \\
& & $(2.72)$ & $(2.73)$ & $(3.41)$ & $(3.32)$ & $(6.17)$ & $(3.73)$ \\
& & & & & & & \\
Observations & 33,167 & 33,168 & 33,138 & 19,490 & 19,409 & 11,949 & 13,950 \\
\hline B. RIGHT BLOCK & & & & & & & \\
Woman & $-4.50^{* * * *}$ & $-2.22^{* * *}$ & $-4.01^{* * *}$ & $-4.98 * * *$ & $-3.83 * * *$ & $-2.90 *$ & -1.81 \\
Children * Woman & $(0.71)$ & $(0.85)$ & $(0.92)$ & $(1.12)$ & $(1.11)$ & $(1.58)$ & $(1.24)$ \\
& & $-4.75^{* * *}$ & $-2.91 *$ & -2.76 & -2.04 & -1.41 & -0.32 \\
New Children * Woman & & $(1.55)$ & $(1.54)$ & $(2.00)$ & $(1.87)$ & $(2.91)$ & $(2.13)$ \\
& & -3.70 & -0.90 & 0.33 & -0.10 & -2.15 & -2.95 \\
& & $(3.41)$ & $(3.37)$ & $(4.20)$ & $(4.02)$ & $(8.42)$ & $(4.58)$
\end{tabular}




\begin{tabular}{lccccccc} 
Observations & 30,317 & 30,317 & 30,291 & 18,063 & 17,859 & 10,260 & 13,259 \\
\hline Election Sample & $91-2010$ & $91-2010$ & $91-2010$ & $98-2010$ & $98-2010$ & $98-2010$ & $98-2010$ \\
\hline Supply Controls & & $\mathrm{x}$ & $\mathrm{x}$ & $\mathrm{x}$ & $\mathrm{x}$ & $\mathrm{x}$ & $\mathrm{x}$ \\
Demand Controls (ind) & & $\mathrm{x}$ & $\mathrm{x}$ & $\mathrm{x}$ & $\mathrm{x}$ & $\mathrm{x}$ \\
Demand Controls (pol) & & & $\mathrm{x}$ & $\mathrm{x}$ & $\mathrm{x}$ \\
Freshmen Omitted & & & & $\mathrm{x}$ & $\mathrm{x}$ \\
Only on Ballot in $\mathrm{t}+1$ & & & & & \\
\hline
\end{tabular}

Notes: $* * * \mathrm{p}<0.01, * * \mathrm{p}<0.05, * \mathrm{p}<0.1$. Robust standard errors clustered at the municipality level are reported in parenthesis. The dependent variable is a dummy for re-election in election $t+1$. All coefficients are scaled up by 100 to let the point estimates be interpreted as $1.0=1$ percentage point. All specifications include fixed effects for the interaction of year, municipality and party. For definitions of the supply and demand controls, see Table 2. The parties in the left block are the Social Democrats, the Left Party and the Environmental Party. The right block is made up of the Conservative Party, the Liberal Party, the Center Party and the Christian Democrats.

Table SI6. Competition and re-elecion, freshmen excluded, 1991-2010.

\begin{tabular}{lcccccc}
\hline & \multicolumn{2}{c}{ Vote Difference between Blocks } & \multicolumn{2}{c}{ Vote Margin of Governing Coalition } \\
& 1 & 2 & 3 & 4 & 5 & 6 \\
\hline Woman & 0.24 & -0.07 & $-7.34 * * *$ & 0.34 & 0.16 & $-18.56^{* * *}$ \\
& $(1.35)$ & $(1.43)$ & $(1.65)$ & $(1.26)$ & $(1.35)$ & $(4.22)$ \\
Woman * Competition & $15.57 * * *$ & $10.74 *$ & 10.99 & $46.37 * * *$ & $29.60^{* *}$ & $52.17 * * *$ \\
& $(5.57)$ & $(5.83)$ & $(20.29)$ & $(12.99)$ & $(14.83)$ & -17.22 \\
& & & & & \\
Observations & 29,819 & 22,157 & 29,819 & 25,207 & 18,334 & 25,207 \\
Election Sample & $98-2010$ & $98-2010$ & $98-2010$ & $98-2010$ & $98-2010$ & $98-2010$ \\
\hline Supply Controls & $\mathrm{x}$ & $\mathrm{x}$ & $\mathrm{x}$ & $\mathrm{x}$ & $\mathrm{x}$ & $\mathrm{x}$ \\
Demand Controls (ind) & $\mathrm{x}$ & $\mathrm{x}$ & $\mathrm{x}$ & $\mathrm{x}$ & $\mathrm{x}$ & $\mathrm{x}$ \\
Demand Controls (pol) & & $\mathrm{x}$ & & & & $\mathrm{x}$ \\
Women* Municipality F.E & & & $\mathrm{x}$ & & $\mathrm{x}$ \\
\hline
\end{tabular}

Notes: $* * * \mathrm{p}<0.01, * * \mathrm{p}<0.05, * \mathrm{p}<0.1$. Robust standard errors clustered at the municipality level are reported in parenthesis. The dependent variable is a dummy for re-election in election $t+1$. All coefficients are scaled up by 100 to let the point estimates be interpreted as $1.0=1$ percentage point. All specifications include fixed effects for the interaction of year, municipality and party. For definitions of the supply and demand controls, see Table 2. The vote difference between blocks is defined as the three-year moving average of the absolute vote share difference between the right- and left-wing block. The vote margin of the governing coalition is defined as the difference between the combined vote share of all parties in the governing coalition and $50 \%$ of the vote share. 
Table SI7. Competition and re-election, only those remaining on the list, 1991-2010.

\begin{tabular}{|c|c|c|c|c|c|c|}
\hline & \multicolumn{3}{|c|}{ Vote Difference between Blocks } & \multicolumn{3}{|c|}{ Vote Margin of Governing Coalition } \\
\hline & 1 & 2 & 3 & 4 & 5 & 6 \\
\hline Woman & $\begin{array}{c}0.47 \\
(0.88)\end{array}$ & $\begin{array}{l}-0.09 \\
(1.02)\end{array}$ & $\begin{array}{c}10.76^{* * * *} \\
(3.10)\end{array}$ & $\begin{array}{c}0.00 \\
(0.87)\end{array}$ & $\begin{array}{l}-0.52 \\
(0.92)\end{array}$ & $\begin{array}{c}15.28 * * * \\
(1.35)\end{array}$ \\
\hline Woman $*$ Competition & $\begin{array}{c}3.61 \\
(3.68)\end{array}$ & $\begin{array}{c}3.03 \\
(4.27)\end{array}$ & $\begin{array}{c}18.02 \\
(13.84)\end{array}$ & $\begin{array}{c}21.03 * * * \\
(7.92)\end{array}$ & $\begin{array}{c}8.41 \\
(8.19)\end{array}$ & $\begin{array}{c}19.58 * * \\
(9.91)\end{array}$ \\
\hline Observations & 45,851 & 27,112 & 45,851 & 30,583 & 22,518 & 30,583 \\
\hline Election Sample & $94-2010$ & $98-2010$ & $94-2010$ & $94-2010$ & $98-2010$ & $94-2010$ \\
\hline Supply Controls & $\mathrm{x}$ & $\mathrm{x}$ & $\mathrm{x}$ & $\mathrm{x}$ & $\mathrm{x}$ & $\mathrm{x}$ \\
\hline Demand Controls (ind) & $\mathrm{x}$ & $\mathrm{x}$ & $\mathrm{x}$ & $\mathrm{x}$ & $\mathrm{x}$ & $\mathrm{x}$ \\
\hline Demand Controls (pol) & & $\mathrm{x}$ & & & $\mathrm{x}$ & \\
\hline Women* Municipality F.E & & & $\mathrm{x}$ & & & $\mathrm{x}$ \\
\hline
\end{tabular}

Notes: $* * * \mathrm{p}<0.01, * * \mathrm{p}<0.05, * \mathrm{p}<0.1$. Robust standard errors clustered at the municipality level are reported in parenthesis. The dependent variable is a dummy for re-election in election $t+1$. All coefficients are scaled up by 100 to let the point estimates be interpreted as $1.0=1$ percentage point. All specifications include fixed effects for the interaction of year, municipality and party. For definitions of the supply and demand controls, see Table 2. The vote difference between blocks is defined as the three-year moving average of the absolute vote share difference between the right- and left-wing block. The vote margin of the governing coalition is defined as the difference between the combined vote share of all parties in the governing coalition and $50 \%$ of the vote share 